\title{
Exílio, tolerância e escrita da história a partir da trajetória de Pierre Bayle (1647-1706)
}

\author{
Exile, tolerance and writing of history from Pierre Bayle's trajectory (1647-1706)
}

Jacson Schwengber

\author{
Doutorando do PPGH - Universidade Federal do Rio Grande do Sul \\ Bolsista Conselho Nacional de Desenvolvimento Científico e Tecnológico (CNPq) \\ jacsonhist@gmail.com
}

Resumo: Este artigo propõe abordar a trajetória intelectual de Pierre Bayle em seu exílio nas Províncias Unidas, nas últimas décadas do século XVII. Nesta época foi estabelecida uma querela historiográfica entre protestantes e católicos em torno da interpretação dos eventos das Guerras de Religião. Com a Revogação do Édito de Nantes, muitos huguenotes rumaram para o refúgio na Holanda. Foi de lá, que tiveram que encontrar meios de construir sua versão a respeito do passado da Reforma. Com este estudo, procura-se mapear quais foram as condições que Bayle encontrou no refúgio para produzir seus textos. O intuito é buscar entender qual a relação entre a experiência do exílio, a escrita da história e a defesa da tolerância a partir dos trabalhos deste autor.

Palavras-chave: Exílio, Tolerância, História.

\begin{abstract}
This article proposes to study the intellectual trajectory of Pierre Bayle in his exile in the United Provinces in the last decades of the seventeenth century. At this time a historiographical quarrel was established between Protestants and Catholics about the interpretation of the events of the Wars of Religion. With the Revocation of the Nantes Edict, many Huguenots went to the refuge in the Netherlands. It was from there that they had to find ways to build their version of the Reformation's past. With this research, we seek to map what were the conditions that Bayle found in the refuge to produce his texts. The aim is to understand the relationship between the experience of exile, the writing of history and the defense of tolerance from the works of this author.
\end{abstract}

Keywords: Exile, tolerance, History. 


\section{Introdução}

Relatos de exílios e de exilados habitam as páginas de muitas de nossas histórias. Momentos de violências e traumas que fazem parte de um passado doloroso da humanidade, bem como de seu presente. Nas próximas linhas, se pretende compreender como foi possível que indivíduos forçados a abandonar sua terra natal conseguiram encontrar meios de elaborar uma complexa reflexão historiográfica. Algumas questões-chave serão: que tipo de perspectiva sobre o passado a experiência do desterro pode engendrar e, nessas circunstâncias, que importância e usos se atribui ao passado. O recorte cronológico são os últimos anos do Setecentos, momento em que milhares de protestantes franceses tiveram de buscar asilo em outros países para fugir da perseguição religiosa promovida por Luís XIV. Nesse contexto, um dos principais destinos foi a República das Províncias Unidas, o chamado "Refúgio da Holanda".

Para fins comparativos, segundo Cerny, o Refúgio Huguenote na República Holandesa pode ser examinado como uma prefiguração do êxodo, maior e mais dramático, de intelectuais europeus pós 1933 para os Estados Unidos (CERNY, 1987: 5). Grande parte da história das Províncias Unidas, com exceção da segunda metade do século XVIII, foi marcada pelo constante influxo de imigrantes para o seu território. Desde a queda da Antuérpia, em 1585, até a revogação do Édito de Nantes, em 1685, milhares de exilados buscaram abrigo na Holanda (BUNGE, 2018: 23). Neste artigo, proponho uma análise a respeito da trajetória de um exilado em particular: Pierre Bayle (1647-1706), também cognominado por seus pares como “o filósofo de Roterdã”. Esse autor será nosso fio condutor na intensa querela historiográfica que, no final do Seiscentos, dominou o contexto letrado de língua francesa.

Pierre Bayle $^{1}$ nasceu no vilarejo de Carla. Uma pequena cidade da região do Pays de Foix, no sudoeste da França e muito distante de Paris. Segundo filho de uma família de cristãos protestantes (seu pai foi ministro da igreja local), esteve durante toda sua juventude situado na periferia da civilização francesa — seja em termos confessionais, intelectuais ou geográficos. Ele aprendeu a ler e escrever em uma pequena escola de sua vila. Depois, sua formação foi complementada na biblioteca do pai. Contudo, não pode ingressar na idade própria em uma instituição de formação superior. Os recursos econômicos da família Bayle eram modestos e, dos três filhos, só

\footnotetext{
${ }^{1}$ Para as informações biográficas de Pierre Bayle consultei LABROUSSE (1985), BOST (2006).
} 
tinham condições de custear os estudos de um deles. Jacob Bayle (1631-1685) se beneficiou do privilégio de ser o primogênito e foi enviado ao Collège de Puylaurens.

No ano de 1666, quando contava com 19 anos, Bayle finalmente pode dar início aos estudos preparatórios de humanidades. Conforme seus biógrafos, para sua família era evidente que concluiria seus estudos para um dia, a exemplo de seu pai e de seu irmão mais velho, assumir o ministério de alguma igreja reformada. Porém, Pierre Bayle tomou uma decisão surpreendente. Em 1668, com 21 anos de idade, fixou residência em Toulouse e se matriculou numa instituição de ensino jesuítica. No ano de 1669, converteu-se ao catolicismo, provavelmente pela pressão de seus mestres da Companhia de Jesus. Se a conversão surpreendeu, mais surpreendente foi sua reconversão para antiga fé protestante, menos de um ano depois. No final do século XVII as leis francesas eram bastante duras contra aqueles que abjuravam a religião católica. ${ }^{2}$ Por isso, no ano de 1670 , foge para Genebra na Suíça.

Antes de seu exílio definitivo nas Províncias Unidas, permaneceu por dois anos em Genebra, lugar onde pode se refugiar e dar prosseguimento a sua formação. Porém, suas condições materiais de subsistência eram modestíssimas. Basicamente trabalhava como preceptor de crianças em troca de teto e alimentação. Em 1682 retorna para a França. Na cidade de Rouen volta a exercer a função de preceptor, atividade que ainda lhe confere ganhos modestos mas melhores que sua situação na Suíça. Temendo perseguição religiosa, adotou o nome falso de Bèle. Foi nessa condição de anonimato e clandestinidade que seguiu para Paris. Permaneceu na capital por menos de um ano e em péssimas condições. Sempre sonhou com o ambiente cultural parisiense, mas quando lá chegou não dispunha de meios financeiros nem de contatos que lhe dessem acesso aos espaços letrados da cidade. Sua situação melhorou um pouco quando, em 1675, foi indicado para o posto e professor na Academia de Sedan.

A rigor, nesse primeiro momento, Bayle não ficou senão dois anos no exílio. Contudo, ainda que de 1672 até 1680 tenha permanecido em solo francês, sua situação de clandestinidade praticamente o reduzia a condição de um desterrado em sua própria pátria. Some-se a isso, retornar ao reino não significou o fim do isolamento parental. Jamais voltou a ver os pais e os irmãos. Rouen, no noroeste da França, e Sedan, no nordeste, distavam muito do lugar em que nasceu e cresceu e onde seus familiares

\footnotetext{
${ }^{2}$ A partir de 1665 os relapsos (isto é, católicos que se convertiam ao protestantismo) eram punidos com a prisão ou o banimento (DELUMEAU, 1989). Bayle era protestante, se converteu ao catolicismo e logo retornou a sua antiga fé. Dessa forma, quanto novamente se converteu ao calvinismo, de acordo com a lei da época, se tornou um relapso.
} 
seguiram vivendo. Sua situação viria a se deteriorar ainda mais. Em 1681, na esteira da intensificação das políticas persecutória promovidas por Luís XIV, a Academia de Sedan foi suprimida. Neste ano Bayle partiu para seu desterro na Holanda, permanecendo na condição de exilado até o fim de sua vida, em 1706.

O destino de Bayle não foi um caso isolado. Por causa da intolerância religiosa, milhares de huguenotes tiveram de se exilar. Calcula-se que em torno de 200 mil indivíduos da Igreja Reformada buscaram refúgios em outros reinos da Europa: 22 mil na Suíça, 25 mil em Brandemburgo (na época um reino alemão autônomo e convertido ao protestantismo desde 1539), 2 mil na Suécia e Dinamarca, cerca de 50 mil na GrãBretanha e por volta de 60 mil nas Províncias Unidas (DELUMEAU, 1989: 196). Os números não são exatos, mas se nota que o maior contingente de exilados se dirigiu ao território neerlandês, ao qual Bayle chamou de "a grande arca dos fugitivos" ("la grande arche des fugitifs") (BAYLE, 1740: "KUCHLIN"). ${ }^{3}$ Mas o que causou esse deslocamento humano em massa?

\section{Intolerância religiosa no reinado de Luís XIV}

No reino da França, desde 1598, os huguenotes vivam sob o regime do Édito de Nantes. Esta lei foi promulgada com o objetivo de encerrar as guerras civis que, desde 1562, foram travadas entre católicos e protestantes. Com o decreto foram garantidos alguns direitos e proteções às comunidades cristãs reformadas da França. Com essa atitude oficial de compromisso pretendia-se colocar fim a sangrenta guerra civil. Quando Bayle nasceu, segunda metade do Seiscentos, os protestantes representavam algo em torno de 5\% da população francesa (CHAREYRE, 2002). Portanto, seguiam sendo uma minoria. Não se deve exagerar os efeitos práticos do Édito, pois mesmo estando em vigor em várias ocasiões os huguenotes viram suas garantias violadas. Todavia, o cotidiano era mais tranquilo do que nos tempos de conflito. Nos anos entre 1630 e 1670, os reformados não sofreram perseguições graves - pelo menos não com o grau de violência empregado no passado (PERRY, 1973: 4). Mas essa situação não perdurou.

\footnotetext{
${ }^{3}$ Nos estudos baylianos, quando se faz referência a textos do Dicionário Histórico e Crítico se convencionou indicar o nome do artigo e, quando for o caso, a letra que indica o comentário da nota de pé de página (por exemplo: rem. A, rem. L, etc.). Isso porque a paginação e o conteúdo dos textos variam conforme a edição.
} 
$\mathrm{Na}$ segunda década do reinado de Luís XIV, aumentou a pressão do clero católico para que o soberano reunificasse a Igreja. O próprio monarca, a exemplo de seu pai, Luís XIII, tinha o objetivo de acabar com a dualidade religiosa de seu reino, apenas exitava quanto ao método (DELUMEAU, 1989: 190). Antes de intensificar a perseguição aos huguenotes, adotou táticas dissuasórias. Desde o início do século XVII, os protestantes haviam sido desarmados, todas suas praças fortes foram destruídas e não podiam ocupar postos militares. O Rei Sol, por sua vez, negou-lhes mercês e impediuos de ocupar cargos na máquina burocrática da Coroa. Ao mesmo tempo, eram oferecidos benefícios aos convertidos. Procurava-se por meio dessas estratégias enfraquecer as comunidades reformadas, incentivando que os protestantes abandonassem seus grupos confessionais. Nesse jogo de poder existia uma zona cinzenta ente o incentivo e a ameaça. Porém, nas últimas décadas do Setecentos, políticas de força foram aplicadas de forma sistemática. A partir daquele momento, as ambiguidades se desfizeram e a violência ficou explícita.

Em 1681, mesmo ano em que foi suprimida a Academia de Sedan, teve início as dragonadas. Consistiam em tropas católicas que promoviam conversões forçadas. No deslocamento desses regimentos militarizados, os calvinistas ficavam obrigados a fornecer alojamento e alimentação para os exércitos que requisitassem permanência em suas propriedades. Por essa época, também foi autorizado a conversão de crianças a partir de sete anos de idades, independente da vontade dos pais. Templos da Igreja reformada eram vandalizados, interditados ou mesmo destruídos. No ano de 1684, regimentos de dragões foram novamente mobilizados. Dessa vez, aqueles protestantes que resistissem se converter ao catolicismo foram ameaçados com o confisco de seus bens e envio para trabalhos forçados em galés (DELUMEAU, 1989: 189-194). Como, na pática, não havia mais qualquer salvaguarda aos huguenotes e, segundo se conta, convencido de que o calvinismo havia sido extirpado por completo de seus domínios, Luís XIV revogou o Édito de Nantes, em 18 de outubro de 1685.

Antes da Revogação, o clero católico colocou em funcionamento uma verdadeira máquina de propaganda antiprotestante. $\mathrm{O}$ intuito era criar um ambiente propício para a supressão das garantias previstas no Édito de Nantes. Para justificar as políticas de intolerância foram escritos livros de história, nos quais se criava um enredo em que os huguenotes figuravam como os culpados de cindir a unidade da Igreja e, por conseguinte, do reino da França. Nessas versões, eram os protestantes, e unicamente eles, os responsáveis pelo martírio e pelos massacres genocidas resultantes da longa e 
sangrenta guerra civil do século XVI. Depois da Revogação, a historiografia dos partidários católicos (leigos e membros do clero) focou na justificação histórica das medidas adotadas por Luís XIV.

No contexto francês do século XVII, os protestantes foram militarmente neutralizados. Porém, encontraram meios de recorrer ao passado e construir uma contra narrativa. A querela historiográfica estabelecida entre os anos de 1670 e 1690 levou a reconsiderações sobre os próprios fundamentos do conhecimento histórico. É importante reconhecer que os dois lados contribuíram para a sofisticação das técnicas de pesquisa, muitas delas presentes no universo acadêmico até nossos dias. Mas é igualmente importante ressaltar que foi uma disputa politicamente assimétrica. Um dos lados da contenda teve de construir suas posições no exílio. Nesse sentido, os principais tratados historiográficos protestantes foram aqueles escritos no Refúgio da Holanda.

\section{Contexto holandês}

O contexto neerlandês era atípico por diversos motivos. Numa Europa composta, em sua maioria, por monarquias, as Províncias Unidas se organizaram como uma república. Sua elite dirigente era eminentemente urbana, de origem plebeia e vinculada ao comércio. Bem diferente, por exemplo, das elites de reinos como França, Portugal ou Espanha, as quais possuíam matiz aristocrático, muitos de seus membros eram terratenentes e, com a consolidação dos modelos absolutistas, cada vez mais dependentes das mercês do rei. Na Holanda, por esse tempo, se valorizava o mérito individual, quando em outras partes ao seu redor vigoravam os valores de prestígio familiar e do privilégio. Mas, quando visto em retrospectiva, talvez um dos traços mais admiráveis das Províncias Unidas foi o grau de tolerância vigente. Isso porque, nos séculos XVI e XVII, a intolerância era entendida como virtude: "uma espécie de integridade moral ou firmeza para com os preceitos morais, algo próximo da noção de austeridade" (ALMEIDA, 2001: 38). Nos inícios da era moderna "amar e praticar sua religião significava muitas vezes combater a de outrem" (DELUMEAU, 1989: 162).

No seu exílio, Bayle escreveu aquele que provavelmente foi o mais radical dos tratados em defesa da tolerância escrito na Idade Moderna - o Commentaire Philosophique (1686). Quando Bayle atribuiu um sentido positivo a ideia de tolerância, 
ele estava ressignificando o sentido que até então majoritariamente se conferia ao termo. De acordo com a pesquisadora Maria Cecília P. de Almeida:

[...] Bayle tenta inverter o sentido negativo que esta palavra tinha nos séculos XVI e XVII, ao sustentar que [tolerância] tem um valor intrínseco, fundado na razão. No século XVI a palavra tolerância mantém o máximo de sua carga negativa: tolerar então era sofrer, suportar pacientemente um mal inevitável, como se se tratasse de uma doença ou de uma infecção [...] Também era comum que a tolerância designasse uma atitude de leniência frente ao mal ou à falta. Indicava uma espécie de conivência ou aceitação de um erro. Quem era 'tolerante' poderia ser acusado de indiferença religiosa, ou mesmo de ter mentalidade irreligiosa, quando não de subversão (ALMEIDA, 2011: 37-38).

Não era fácil, ainda que representantes da classe dirigente quisessem, manter uma política de tolerância. Henrique IV, rei da França, foi assassinado por um fanático católico que o considerou excessivamente complacente para com os protestantes (DELUMEAU, 1989:162). Por isso, a grande variedade de crenças e práticas religiosas permitidas nas Províncias Unidas era, no século XVII, comumente tomada como sinal de degeneração moral da sociedade holandesa. Havia a crença amplamente compartilhadas de que a ausência de unidade religiosa levava inevitavelmente ao colapso da ordem política. A experiência neerlandesa, ao fim e ao cabo, foi uma refutação prática de tal hipótese.

Receber estrangeiros não era novidade para os holandeses. Antes da Revogação do Édito de Nantes “esta terra tolerante e afável tinha já o hábito de ver chegar os ingleses que se exilavam da pátria, os realistas no tempo de Cromwell, os republicanos no reinado de Carlos II". Recebeu eminências letradas da época como John Locke ${ }^{4}$ (1632-1704), e Shaftesbury (1671-1713). A Holanda oferecia as diferentes religiões "uma terra de asilo". Ali, conviviam templos, igrejas e sinagogas. Todas essas liberdades, atípicas para a época, acabam levando a certa idealização a respeito das Províncias Unidas. Nas palavras de Paul Hazard quando, em 1685, os protestantes franceses solicitaram refúgio, a Holanda "soube encontrar-lhes lugares nas oficinas, no

\footnotetext{
${ }^{4}$ Locke se exilou da Inglaterra devido sua oposição ao Rei Carlos II. O dado curioso é que, décadas antes, quando Cromwell venceu a guerra civil de 1648, foi Carlos II quem buscara asilo na Holanda.
} 
exército e nas escolas. Aceitou-os no meio dos seus, porque era também protestante, porque odiava a política de Luís XIV, e porque era humana” (HAZARD, 1971: 65-66).

Difícil, senão inviável, averiguar historicamente a predisposição humanitária atribuída a sociedade holandesa. No entanto, estudos indicam que a adoção de políticas de tolerância respondeu a demandas materiais. Necessidades práticas, mais do que idealismo, parecem estar na raiz da forma pela qual se organizou o sistema político republicano. Entre o final do Seiscentos e início dos Setecentos, os governantes do novo Estado que se formava tinham como tarefa organizar uma sociedade religiosamente dividida. Tentar impor a unidade confessional, católica ou protestante, poderia levar a conflitos internos. Os regentes decidiram priorizar a ordem e tranquilidade política doméstica mais do que zelar pela pureza confessional, o que pode ser visto, segundo J. L. Price, como um passo significativo no rumo da secularização. Não foi apenas matéria de escolha, mas cálculo do possível naquelas circunstâncias. Existia a vontade de unificação doutrinal, mas não se dispunha dos instrumentos de coerção necessários para impor tal medida. Os governos provinciais e as autoridades locais guardavam com zelo sua autonomia. No sistema político descentralizado da República, não havia uma autoridade que, sozinha, fosse capaz de estabelecer uniformidade para todo território. No passado recende, tentativas de suprimir os reformados na Holanda mostraram que os governos locais, principalmente das cidades, eram relutantes em agir contra seus próprios cidadãos a mando das autoridades externas - como Bruxelas, por exemplo. Depois da revolta que consolidou a soberania das Sete Províncias Unidas, a maioria dos regentes não estava, de foram alguma, inclinada a substituir uma forma de perseguição religiosa por outra (PRICE, 1998: 87-88).

Existiam limitações de ordem prática para a imposição de políticas confessionais persecutórias, mas igualmente havia limites para o que poderia, na prática, ser abertamente tolerado. A flexibilidade do que era permitido variava consideravelmente de região para região. Não foi aplicada uma política sistemática de censura, mas existiam dispositivos que, por meio de pressão social ou perseguição localizada, restringiam a circulação de valores e pontos de vista do catolicismo (PRICE, 1998: 88). O quadro geral possuía nuances. Os católicos estavam em melhor situação do que muitas das minorias religiosas da Europa e na prática conseguiam meios de burlar as leis contra o exercício de sua fé. Não obstante, estavam excluídos da atividade política e de ocupar cargos públicos e tiveram de realizar seus cultos sob aparência de sigilo (PRICE, 1998: 93). Os seguidores da Igreja de Roma tinham liberdade de consciência, 
mas não de culto. Como os franceses calvinistas, os católicos neerlandeses eram espécies de outsiders em sua própria sociedade. Não é o caso de negar a existência de espaços para exercício de algumas liberdades, mas, como se nota, o contexto não era exatamente a terra afável descrita por Paul Hazard. ${ }^{5}$

Sobre a Holanda também é muito debatido quanto ao caráter laico de seu governo e da indiferença religiosa de seus habitantes. Segundo se conta, circulava nos ambientes comerciais a ideia de que "quem emprega seu zelo a converter o judeu é bom cristão, mas não um bom negociante". Também havia o ditado segundo o qual "não há negócio nem banco possíveis, se for pedido a todas pessoas o certificado de batismo" (HAZARD, 1971: 65). No entanto, outra vez a questão possui nuances. Existiam tensões na relação entre administração civil e Igreja, ainda assim, esses eram elementos intimamente interligados. As Províncias Unidas não estabeleceram uma religião de Estado, mas a Igreja Reformada funcionava como representante da religião oficial. Nenhum neerlandês estava obrigado a se converter a ela ou lhe prestar serviço. Pode ter existido vantagens, sociais e políticas, para a adesão à Igreja Reformada, mas não houve coerção legal para obrigar conversões (PRICE, 1998: 90). Além disso, não era um estado propriamente calvinista, ou mesmo protestante, pois os católicos, ainda que sujeitos as restrições mencionadas acima, representavam larga parcela de sua população (PRICE, 1998: 93).

Os judeus, diferente dos católicos, tinham direito tanto de consciência quanto de culto. Os limites ao catolicismo eram mais estreitos porque os dirigentes neerlandeses viam no clero uma força política potencialmente desestabilizadora, devido principalmente as conexões internacionais que tinham com nações católicas rivais como Espanha e França. Mas o ponto fundamental é que, se foi permitido o culto nas sinagogas e se existiam ressalvas com relação a Igreja Católica, o ateísmo, por sua vez, era considerado inadmissível. A descrença absoluta significava a ausência dos fundamentos morais sem os quais não pode perdurar uma sociedade civilizada. A questão da irreligiosidade é emblemática para a compreensão de que a organização das coletividades humanas não depende somente da vontade de seus dirigentes. A ojeriza a figura do ateu era elemento compartilhado pela sociedade em geral e marcava um limite para além do qual a política pública laica não deveria ir (PRICE, 1998: 89).

\footnotetext{
${ }^{5}$ Para um debate sobre as concepções teóricas e práticas da ideia de tolerância consultar (GROS, 2017); para uma síntese que descreve os limites das liberdades confessionais e políticas na Holanda consultar (BUNGE, 2018).
} 
Títulos de obras como o Tratado teológico-político de Espinosa, são indicativos de que - embora se identifique, aqui e ali, a consolidação de valores laicos $^{6}$ interesses de Estado e de religião, amiúde, se confundiam. Os governantes das Províncias Unidas não foram, e não poderiam ter sido, protagonistas de uma política totalmente secular em uma sociedade que continuava a se definir em termos religiosos. A sociedade neerlandesa que se formava no século XVII se encontrava na interseção de valores seculares emergentes e de uma cultura religiosa profundamente enraizada. Governantes e governados, de formas variadas, encontravam-se nos dois campos desse espectro (PRICE, 1998: 89).

\section{Exílio e escrita da história}

Não se deve superestimar as liberdades existentes nesse tempo e lugar; elas não eram absolutas. Porém, é inequívoco que a Holanda foi um lugar privilegiado para produção e circulação de ideias heterodoxas por meio das suas várias oficinas tipográficas. Entre as heterodoxias do pensamento talvez a mais potente, e carregada de efeitos até nossos dias, foi a defesa da tolerância como virtude epistêmica e política. Os dois grandes teóricos da tolerância do século XVII foram o francês Pierre Bayle e o inglês John Locke. Ambos estiveram, por motivos diferentes, exilados nas Províncias Unidas. Ali, encontraram o principal centro tipográfico europeu e um espaço para formular suas ideias. Não estavam em um lugar de liberdade irrestrita. Contudo, "embora relativa", tal liberdade era "rara e bela" (HAZARD, 1971: 65).

Foi no exílio da Holanda que esses dois pensadores escreveram obras que, segundo alguns analistas, trouxeram consequências radicais para a epistemologia da história (POCOCK, 2004: 56). Na década de 1670, sob o governo absolutista dos Stuart, John Locke começara a trabalhar no seu Ensaio sobre o entendimento humano. Contudo, só veio a concluir esse tratado durante seu exílio de seis anos nas Províncias Unidas (KOSELLECK, 1999:49). Seguindo a leitura do Ensaio, chega-se ao seguinte postulado: a mente pode formar, mas não validar ideias. Portanto, havia limites para o intelecto humano para formar sistemas de crenças. Isso significou uma mudança nas formas e nos motivos pelos quais se olhava para o passado. As operações mentais, que

\footnotetext{
${ }^{6}$ Inclusive esse e outros tratados de Espinosa contribuíram para a consolidação de uma abordagem laica do conhecimento e da política.
} 
Locke analisou em um mundo de objetos, foi transposto para o mundo dos discursos. Por toda a Europa ou, pode-se dizer de forma genérica, no interior da República das Letras, o fascínio pela literatura clássica e eclesiástica permanecia vigoroso. Porém, adotava-se, agora, outra postura diante desse material. No lugar da autoridade inerente aos textos, se consolidava o estudo sobre as especificidades das mentes que produziram esses textos. Foi colocado em pauta que efeitos as leis, os costumes, as opiniões e as ideias tiveram, no passado, sobre as formulações teológicas (também filosófica e científicas). Assim, mesmo sem ser historiador ou ter teorizado sobre a história, Locke contribuiu imensamente para o saber historiográfico (POCOCK, 2004: 64-68).

Os trabalhos escritos por Pierre Bayle são bastante idiossincráticos e suas premissas teóricas, muitas vezes, não convergem com as perspectivas epistemológicas de Locke. No entanto, é digno de nota que ambos tenham encontrado em seus refúgios, nas cidades de Amsterdã e de Roterdã, possibilidades de desenvolverem seus projetos intelectuais. Apesar das diferenças entre seus trabalhos, ambos contribuíram para se abordar aquilo que poderíamos chamara de subjetividade do pesquisador. Bayle fez isso oferecendo uma visada quanto a parcialidade e o ponto de vista daquele que escreve. Ao olhar para os textos sagrados não procurou a revelação, mas a história da religião. Nos sistemas filosóficos não parece ter esperado encontrar uma verdade, mas uma coleção de doxografias. Em resumo, efetuava uma leitura crítica menos para questionar as heresias e verdades, e mais para compreender como se produz a autoridade que define algo como herético ou verdadeiro.

Seria possível estabelecer uma relação na colocação em evidência do ponto vista como princípio constitutivo do saber histórico e a experiência do exílio? Essa pergunta não é nova. A tradição ocidental escolheu e construiu como ponto de emergência da escrita da história o universo cultural greco-romano Antigo. Deixemos passar, por ora, os aspectos artificiosos a partir dos quais nossa disciplina criou sua autoimagem. $\mathrm{O}$ ponto é que, desde esse momento entendido como fundador, a tópica do exílio figura na configuração de nosso saber. Nesse sentido, o exílio é ao mesmo tempo um tema sobre o qual a história fala e também, segundo alguns estudiosos, uma condição fundamental para que se começasse a escrever história num sentido que, de uma forma ou de outra, ainda nos é comum.

O classicista neozelandês Ronald Syme sustentava que o exílio pode, por si só, constituir um(a) historiador(a). Isso porque produz um estranhamento e um 
distanciamento do olhar. ${ }^{7}$ Ao se desterritorializar, é como se o ponto de vista ficasse mais cosmopolita. Contudo, deve se ter cuidado na aplicação do termo exílio de forma genérica a todos os historiadores Antigos que por diferentes motivos foram forçados (ou escolheram) viver longe de sua terra natal (DILLERY, 2007). Por certo foram diferentes das experiências modernas aquelas vivenciadas pelos Antigos. Mas a remissão a eles não é sem razão. Quando os autores modernos formularam suas concepções de história o fizeram buscando autorizá-las a partir do legado clássico. Dessa maneira, na Idade Moderna foi constituído um cânone historiográfico onde figuram nomes como os de Heródoto, Tucídides e Políbio (203 a.C.- 120 a.C.); todos eles, de diferentes maneiras, vivenciaram a experiência do desterro.

Os manuais de história do século XVII davam espaço para tratar da contribuição dos modelos historiográficos de Heródoto e Tucídides, contudo não deram tanta atenção a condição de degredo a que eles estiveram sujeitos. Políbio, por sua vez, era reiteradamente abordado em função de sua condição de escritor desterrado. Os tratados modernos de escrita da história adotaram o discurso polibiano como uma de suas principais referências, tendo como fundamentos sua pretendida posição de imparcialidade, a qual ocupava justamente em função de seu exílio. Como "grego da diáspora, julgava sua palavra livre de embustes e interesses" (LIMA, 2006: 172). Tucídides era outro nome evocado como autoridade nos manuais de história da Idade Moderna, contudo, curiosamente, não se dava relevo a sua experiência de degredo.

\footnotetext{
${ }^{7}$ Nas palavras do autor: "exile may be the making of an historian [...] permiting him to look at things with detachment, if not in estrangement" (SYME, 1962: 40 apud DILLERY, 2007: 51). Na verdade, Syme não flexiona o gênero do sujeito do conhecimento histórico. Ele, como praticamente totalidade dos autores de sua época, escreve historiador(es) como palavra que designa qualquer um(a) que se dedica a pesquisar e escrever história. $\mathrm{O}$ mesmo ocorre nas fontes modernas que serão aqui utilizadas, com o agravante de que os textos escritos nos séculos XVII e XVIII não apensas mascaram a contribuição das mulheres para epistemologia do conhecimento histórico utilizando a palavra historiador(es) apenas no masculino, como deliberadamente consideravam ser uma impossibilidade mulheres escreverem história. Apesar das tentativas de controle do discurso masculino, sabe-se que muitas escritoras contribuíram para a historiografia. A historiadora Bonnie G. Smith expandiu nossa compreensão a respeito das condições materiais da produção do discurso histórico no passado e complexificou a categoria "historiador": "a história dos últimos dois séculos não tem sido escrita em sua maior parte por homens e tampouco diz respeito unicamente a homens". Contudo, até recentemente "milhares de historiadoras continuavam a ser chamadas de amadoras, sem as associações institucionais dos profissionais do sexo masculino" (SMITH, 2003: 23). Smith concentra seu estudo no século XIX e início do XX. A historiadora Mary Spongberg oferece uma descrição das dinâmicas de poder envolvidas na masculinização da categoria "historiador" desde sua herança Antiga. Ela realizou uma incrível história da historiografia onde apresenta o grande número de historiadoras que, desde o Renascimento, compilaram informações sobre o passado. Além do apanhado de vidas e obras fascinantes, esse trabalho evidencia o funcionamento do patriarcado e da misoginia na cultura ocidental, que, no caso da história da historiografia, levou ao apagamento das contribuições de mulheres, excluindo-as da categoria das pessoas que poderiam escrever obras reconhecidas como "História" (SPONGBERG, 2002).
} 
Embora chame atenção que o próprio texto tucidideano destaca a condição do exílio como constitutiva da perspectiva imparcial do historiador:

Atingiu-me também uma condenação ao exílio que me manteve longe de minha terra por vinte anos após o meu período de comando em Anfípolis e, diante de minha familiaridade com as atividades de ambos os lados, especialmente aquelas do Peloponeso em consequência de meu banimento, graças ao meu ócio pude acompanhar melhor o curso dos acontecimentos (TUCÍDIDES, 5, 26, grifos meus).

Desde a Antiguidade se fala do problema de discernir entre um historiador imparcial e objetivo de um logógrafo panegirista e detrator — ou seja, este último, alguém que se dedica a enaltecer os valores de sua pátria e de seu soberano e a vituperar as outras nações e seus governantes. Quando o historiador faz mais a propaganda do que o relato fidedigno acaba por atuar como advogado de uma das partes, e não como juiz. Dessa forma, pairam dúvidas em relação ao relato histórico. Por quais critérios e através de que meios discernir se quando um historiador romano escreveu sobre Roma não estava comprometido por orgulho pátrio em fazer o elogio de seu torrão natal. Como poderia, nesse caso hipotético, falar de outros povos e impérios que não conheceu. Nesse sentido, os textos antigos apresentam a ideia de que o historiador, uma vez no exílio, adquire novos pontos de vista. Pode falar de sua terra estando fora e pode relatar sobre outros povos estando, ainda que temporariamente e de forma precária, dentro. Não entrarei no mérito do quão ingênuo ou simplificador essa fórmula possa ser. Independente disso, identificamos na literatura da modernidade ressonâncias do tema.

Pierre Bayle foi leitor dos clássicos e conheceu de perto os problemas relativos aos discursos partidários. A querela historiográfica entre protestantes e católicos converteu os relatos históricos em ferramentas de justificação para cada um dos lados. As intensas disputas sobre diferentes versões do passado das Guerras de Religião foi um fenômeno particularmente intenso no contexto de língua francesa - o Refúgio da Holanda fazia parte desse contexto. Os polemistas católicos responsabilizaram os protestantes pela divisão da Igreja e carregaram nas tintas o caráter violento da Reforma. Os argumentos de Pierre Nicole (1625-1695) são exemplares a esse respeito: 
Quando se pressiona os assim chamados reformados para remontar à sua origem, e se representa em histórias exatas (justes Histoires) o começo e o progresso de sua seita; quando se expõe ao mundo quem foram esses reformadores de todos os Concílios e de todos os Santos Padres, quando se faz o retrato de seus costumes e de suas máximas, quando os seguimos em suas campanhas sangrentas e se mostra eles fomentando sedição e revolta em todos os lugares contra todos os poderes eclesiásticos e seculares, cobrindo toda Europa de sangue, não há nada que irrite mais vivamente a amargura de seu zelo ou os faça proferir os mais altos clamores (NICOLE, 1684: 211, grifos meus). ${ }^{8}$

Nessa e em outras histórias escritas por católicos, o enredo contava que foram os protestantes os responsáveis pelas guerras civis na França. Procurava-se, por meio de usos da interpretação do passado, consolidar o entendimento de que os huguenotes não eram verdadeiros súditos franceses, pois jamais se integraram a sociedade. Esse discurso se coadunava com as políticas de intolerância de Luís XIV. Se os membros da Igreja Reformada representavam uma ameaça à integridade da comunidade e do Estado, em nome do bem público era justificável que fossem perseguidos, presos ou mesmo executados.

No início do artigo foi apresentado o resumo de elementos contextuais durante o governo de Luís XIV, podemos, portanto, compreender o quanto para os protestantes a disputa pelo passado se transformara numa questão de sobrevivência política. Jean Claude (1619-1687) - que fora um pastor e entrou em disputa com católicos influentes como Pierre Nicole, Antoine Arnauld e Bossuet - teve que escapar da perseguição e partiu para o exílio, no ano de 1685. Na comunidade francesa do Refúgio da Holanda, Jean Claude escreveu um importante livro: Les plaintes des protestans, cruellement oprimez dans le royaume de France [Denúncias dos protestantes, cruelmente oprimidos no reino da França, de 1686]. Essa obra marca um contraponto ao discurso que negava a violência contra os huguenotes.

\footnotetext{
8 "Quand on presse les Pretendus reformez de remonter a leur origine, \& qu'on represente dans de justes Histoires Ie commencement \& Ie progrez de leur Secte; qu'on decouvre au monde quels etoient ces reformateurs de tous les Conciles, \& de taus les Peres; que l'on fait Ie portrait de leurs moeurs, \& de leurs maximes, qu'on les suit dans leurs demarches sanglantes, \& qu'on les fait voir allumant par tout la sedition \& la revolte contre toutes les puissances Ecclesiastiques \& Seculieres, \& remplissant toute I'Europe de sang, il n'y a rien qui irrite plus vivement l'amertume de leur zele, ni qui leur fasse jetter de plus grands cris".
} 
Jean Claude reuniu relatos comoventes escritos por amigos e correspondentes seus que se encontravam exilados em várias partes da Europa. Uma das intenções expressas pelo autor era transformar as narrativas dessas experiências em fontes históricas que provavam os excessos cometidos pela França. Como o título indica, o livro quis denunciar essa situação ao resto do continente europeu. Para Claude, tratavase de ousadia inconcebível as falsificações que o clero francês pretendia espalhar por toda parte. Segundo ele, era "querer iludir toda a Europa sobre eventos que ela sabe não por Gazetas ou por Lettres, ${ }^{9}$ mas por isso que é mais autêntico: um número quase infinito de fugitivos [...] que vão levar suas lágrimas e suas misérias aos olhos das Nações mais distantes" (CLAUDE, 1707: 3). O testemunho dado em tempo presente funcionava numa estratégia de política internacional dos refugiados, e como registro para evitar falsificações de uma história futura.

Não é viável no espaço de um artigo retomar o conjunto dos pontos e contrapontos da querela em seus detalhes. Ao todo - entre livros, tratados, manifestos e panfletos - são mais de uma centena de títulos. O que é fundamental aqui é que tenhamos uma noção de seus principais aspectos e a importância que o espaço de exílio na Holanda teve na construção do debate. Nesse momento, acredito, podemos sugerir um contraponto a hipótese de Ronald Syme, apresentada acima e segundo a qual o exílio pode, por si só, constituir um historiador. Por certo a condição de exilado deixou marcas nos trabalhos de Pierre Bayle, como veremos em seguida. Mas o deslocamento do lugar de origem não garante por si só a adoção de um ponto de vista equitativo, tal como aquele que se pressupõe para o modelo ideal de historiador. ${ }^{10}$ Pelo menos não foi esse o caso de Pierre Jurieu (1637-1713).

A retórica incendiária de Jurieu era tão agressiva e partidária quanto a de seus inimigos católicos. Foi explicitado linhas acima que, no contexto francês, a relação entre católicos e protestantes não era politicamente simétrica. O lado da querela ocupado pelos reformados era socialmente precário. Minoria no reino em que nasceram, para defender suas concepções tiveram que rumar para países estrangeiros. Não se trata, portanto, de fazer um juízo de valor quanto a posição adotada por Pierre Jurieu. Não

\footnotetext{
${ }^{9}$ Não soube como traduzir o termo. Seria Letras num sentido amplo de todo qualquer texto. Materiais escritos na forma de livros, tratados ou panfletos.

${ }_{10}$ Dessa vez deixo propositadamente o termo no masculino, pois, esse ideal foi construído numa perspectiva ocidental que pressupõe a figura do homem como sujeito do conhecimento. É de um ponto de vista supostamente universal que os valores de imparcialidade e objetividade se apresentam como virtudes epistêmicas inquestionáveis. Estudos feministas, pós-coloniais e decoloniais tem evidenciado essa quimera epistemológica universalizante, a qual na verdade é mascaramento de sua condição de discurso localizado.
} 
entro no mérito se ela foi correta ou não. O ponto é que ele viveu a experiência do exílio e se dedicou a escrever sobre o passado. Porém, diferente dos exemplos elencados anteriormente, não se preocupou em apresentar os dois lados da contenda de forma equânime. Pierre Bayle, em dado momento da querela, se converteu num dos mais duros críticos dos excessos partidários de Jurieu. ${ }^{11}$

No seu La politique du clergé de France, Pierre Jurieu inicia com as seguintes palavras: "se esta obra cair nas mãos daqueles que se deixam conquistar pelas solicitações urgentes dos inimigos dos protestantes na França, eles finalmente abrirão os olhos para os verdadeiros interesses do Rei e do Reino". ${ }^{12}$ Jurieu, de certa forma, usa a mesma estratégia narrativa inaugurada por Nicole, mas com sinais trocados. Os personagens do livro expõem as manipulações e o crescente processo de corrupção do catolicismo francês. É afirmado que o clero possuí caráter conspirador, sectário e que está sempre pronto a se revoltar contra o rei; que os huguenotes são a fonte mais segura de lealdade sobre a qual soberano poderia depositar sua confiança. Como exemplo de seus argumentos, remete ao suposto complô papista, denunciado em 1679, para assassinar o rei inglês Carlos II. Jurieu assumiu como verdadeiro esse evento que foi, na verdade, uma farsa conspiratória inventada por grupos políticos anticatólicos ingleses (GIBNEY, 2009). O capítulo sobre o complô papista é indicativo da complexidade política e confessional desse período. Pois, se na França os protestantes eram uma minoria perseguida pela política institucional católica, na Inglaterra os papéis se invertiam.

Nesse quadro de partidarismos e intolerância de todos os lados, como escrever uma história não panfletária? Pierre Bayle abordou a questão:

Conheço pessoas que desejariam Histórias da Reforma que não tivessem sido compostas nem por um Católico Romano, nem por um Protestante. Eles imaginam que o interesse de partido e o zelo por sua própria causa, e ainda mais a raiva pela outra religião, levam um escritor a exagerar, ou a suprimir, ou enfraquecer, ou a dissimular as coisas conforme elas possam servir ou prejudicar a honra de seu partido... seria bom aconselhar a um huguenote zeloso de jamais empreender nem a História do Calvinismo, nem aquela do

\footnotetext{
${ }^{11}$ Sobre a disputa entre Bayle e Jurieu ver (LUGT, 2016).

12 "[...] si cet ouvrage tombe entre les mains de ceux qui se laissent vaincre par les pressantes solicitations des ennemis des Protestants en France, ils ouvriront enfin les yeux aux veritables interets du Roy \& du Royaume".
} 
Luteranismo, nem aquela do Édito de Nantes, nem alguma outra dessa natureza. Você tem o coração ressentido, deveríamos lhe dizer...você nos daria não uma História, mas textos de um advogado (BAYLE, 1740: "REMOND" rem. D). ${ }^{13}$

Pegando o conteúdo do excerto, vemos que Bayle imaginou uma narrativa histórica ideal na qual quem narra deve ser estranho a todos os lados em disputa. Esse é um exercício apenas hipotético. Ele sabia que tal exigência, no limite, era irrealizável. No contexto do debate historiográfico no qual estava inserido, quem tomava a palavra irremediavelmente era católico ou protestante. Para escapar da aporia elaborou soluções imaginativas onde mesclava epistemologia e ficcionalização como meio de fugir dos partidarismos. Propôs exercícios intelectuais interessantes, todos eles envolvendo uma tentativa de se pensar enquanto outro, enquanto estrangeiro. Bayle divagou sobre o quão curioso seria uma relação composta por um oriental sobre o ocidente (BAYLE, 1740: "JAPON", rem. A). Outro tema do estranhamento (e que depois veio a ter fortuna na pena de Voltaire) foi a parábola de habitantes da lua que chegam a França (BAYLE, 1737: 306a-307b). Sobre a história do protestantismo e do catolicismo, convidou os leitores e leitoras a se indagar qual seria o ponto de vista de um escritor pagão da antiguidade (BAYLE, 1737a: 573b). Mesmo nesse último caso não guardou qualquer ilusão de neutralidade, pois supôs que provavelmente o autor pagão faria o elogio de suas crenças politeístas em detrimento das confissões monoteístas, fossem representadas pela Igreja Reformada ou pela de Roma.

Bayle escreveu que "todos os que conhecem as leis da História estarão de acordo em que um historiador, se quiser cumprir fielmente suas funções, deve despojar-se do espírito de adulação e do espírito de maledicência”. Apenas um sujeito desterrado (real ou metafórico) alcançaria tal objetivo, pois, exige "esquecer o amor da pátria". No modelo ideal de historiador projetado por Pierre Bayle, este:

\footnotetext{
13 “Je connois des gens qui souhaiteraient des Histoires de la Reforme qui n'eussent été composées ni par un Catholique Romain, ni par un Protestant. Ils s'imaginent que l'intérêt de Parti et le zèle pour sa propre Cause, et plus encore la haine pour l'autre Religion, engagent un Ecrivain à exaggerer, ou à supprimer, ou è extenuer, ou à deguiser les choses selon qu'elles peuvent servir ou nuire à l'honneur de son Parti ... l'on feroit bien de conseiller à un zélé Huguenot de n'entreprendre jamais ni I'Histoire du Calvinisme, ni celle du Luthéranisme, ni celle de l'Edit de Nantes, ni aucune autre de cette nature. Vous avez le coeur ulcéré, lui devroit-on dire ... vous nous donneriez non pas une Histoire, mais des écritures d'Avocat".
} 
Deve esquecer que está num certo país, que foi instruído numa certa comunhão, que é devedor de gratidão a este ou àquele, que tais e tais são seus progenitores ou seus amigos. Um historiador, enquanto no exercício de sua função, é como Melquisedeque, sem pai, sem mãe e sem genealogia. Se lhe perguntarem donde veio, deverá responder: não sou francês, nem alemão, nem inglês ou espanhol; sou habitante do mundo; não estou a serviço do imperador, nem do rei da França (BAYLE, 1740: USSON, rem. F apud CASSIRER, 1994: 281, grifos meus).

Essa espécie de grau zero, Bayle o sabia, era inalcançável. Porém, tinha valor enquanto horizonte. $\mathrm{Na}$ junção de suas identidades de cristão e de erudito, Bayle defendeu que os doutos, para serem dignos desse adjetivo, deviam se fazer humildes. E não via no ambiente letrado orgulho maior do que se pretender irretocável. No seu Dicionário Histórico e Crítico queria fazer a coletânea dos erros, segundo dizia, não para diminuir o valor de esforços dos que o precederam, mas para evidenciar que inclusive os mais sábios entre os mais sábios não eram infalíveis em tudo (BAYLE, 1692: préface). A rigor, não sendo possível ser um outro ou não ser ninguém, o convite era para desconfiarmos de nós mesmos. Quem escreve história deve desconfiar das verdades que lhe são agradáveis

Talvez a maior contribuição de Bayle para o conhecimento histórico moderno não esteja propriamente nos preceitos metodológicos. Mas na compreensão que adquiriu no exílio de que uma história que leve em conta diferentes pontos de vista precisa de um ambiente de liberdade intelectual. Expressou isso, em alguns momentos, com humor trágico. No verbete sobre Jaques Bonfadius (historiador do século XVI), Bayle aproveita o triste destino do personagem para fazer um comentário irônico sobre as chamadas leis da história, as quais remetiam ao Do Orador, de Cícero. Seu comentário diz respeito especialmente a seguinte passagem: "quem ignora que a primeira lei da história é não dizer algo falso? Em seguida, ousar dizer algo verdadeiro?” (Oratore, II, 62). Pois, Bonfadius cometeu a imprudência de seguir essa lei e, por "ousar" escrever livremente acabou ofendendo poderosas famílias de sua região. Os inimigos de Bonfadius acabaram condenando-o a fogueira. Daí o seguinte trecho que Bayle colocou em nota de rodapé: 
Nada mais excelente em teoria do que as ideias do legislador dos historiadores. Ele ordena-lhes não ousar dizer nada que seja falso, e ousar dizer tudo o que é verdadeiro. Mas essas são leis impraticáveis, como aquelas do Decálogo, tendo em conta a situação em que se encontra a raça humana. Se fosse permitido comparar coisas humanas e divinas, dir-se-ia que o legislador dos historiadores teria imitado o legislador dos judeus. Este, baseou suas leis sobre o estado do homem em sua inocência, e não sobre o estado do homem no pecado [...] Embora similares, vamos observar uma grande diferença entre essas leis. Somente uma perfeita sabedoria para viver de acordo com os mandamentos divinos; e seria uma loucura completa efetivar as leis da história. A vida eterna é resultado da obediência ao Decálogo; mas a morte terrena é a mais inevitável consequência da obediência ao legislador dos historiadores (BAYLE, 1740: "BONFADIUS", rem. D). ${ }^{14}$

Bayle ainda complementa, na mesma nota, que mais importante que as leis da história são as leis da prudência. E que se Bonfadius era inocente do crime de sodomia, foi responsável por sua imprudência de dizer a verdade. Assim, recomenda que se um historiador for dizer algo que possa irritar alguma figura poderosa, melhor esperar que esta já tenha morrido e ter certeza que seus descendentes não possam se vingar. Talvez possamos procurar entender suas palavras por algo que está nas entrelinhas: que o melhor seria a existência de um espaço seguro onde quem escreve história não coloca sua vida em risco por expressar seus pontos de vista. Na França conhecera a violência da intolerância católica. Em Roterdã foi perseguido pela ortodoxia calvinista. No contexto de tolerância intelectual, ainda que relativa, das Províncias Unidas foi onde Pierre Bayle teve condições de propor uma sociabilidade literária desprovida de censuras. Não é trivial que nas primeiras páginas do primeiro número de seu periódico, Nouvelles de la république des lettres (NRL), tenha expresso esse reconhecimento:

\footnotetext{
14 “Rien n'est plus beau dans la théorie, que les idées du Législateur des Historiens: il leur commande de n'oser dire rien qui soit faux, \& d'oser dire tout ce qui est vrai; mais ce sont des loix impraticables, tout comme celles du Décalogue dans l'état où le Genre humain se trouve. S'il étoit permis de comparer les choses humaines avec les choses divines, l'on diroit que le Législateur des Historiens a imité le Légiflateur des Juifs (...) Remarquons d'ailleurs une grande différence entre des loix si femblables. Il n'y a qu'une parfaite sagesse, qui puisse accomplir le Décalogue; \& il faut doit être d'une folie achevée, pour accomplir les loix de l'Hiftoire. La vie éternelle est le fruit de l'obéissance au Décalogue; mais la mort temporale est la suite presque inévitable de l'obéissance au Législateur des Historiens".
} 
[A Holanda] tem ainda uma vantagem que não se encontra em nenhum outro país: é concedido aos impressores grande liberdade, o que faz com que, diante das dificuldades de se obter Privilégios, se recorram a eles de todas as partes da Europa [...] Nossas prensas são refúgio tanto de católicos como de protestantes [...] Essa digna liberdade de imprensa, confere, sem dúvida, formidável benefício ao propósito de fazer um periódico acadêmico (BAYLE, 1966: 7b). ${ }^{15}$

Foi nesse periódico onde Bayle começou não só a enunciar suas concepções de história e tolerância, como colocá-la em prática. Esse foi um momento em que não existia o lugar social do intelectual, tal como o entendemos desde Zola e Sartre - ou desde Voltaire. Enquanto homem de letras, Bayle não tinha ingerência direta nos rumos da política institucional. Sua defesa da tolerância significou "uma verdadeira revolução intelectual, uma inversão do pensável” (GROS, 2017: 186). Visto em retrospectiva, suas hipóteses foram vencedoras, mas no momento em que as formulou o impacto foi reduzido. Nas páginas de seus livros, vislumbrou não só uma república de letras livre, como a formação de algo como uma esfera pública de opiniões.

Nas páginas do NRL, Bayle se apresentava como jornalista (journaliste), mas sua função enquanto tal se confundia com a do historiador, pois fazia o juízo das obras sem "preconceitos ou malignidades" (sans prévention, \& sans aucune malignité). No seu periódico estabeleceu os fundamentos de uma ética acadêmica que ainda hoje, se nem sempre na prática, pelo menos em teoria, valorizamos: "declaramos, primeiramente, que não pretendemos estabelecer qualquer preconceito ou a favor ou contra os autores". Diferente dos "senhores da congregação do índice" — o aparato censório da Inquisição - em sua revista "exerceremos antes a função de reportadores do que de juízes, e faremos resenhas fidedignas tanto de livros que nos são contrários como dos que nos são favoráveis". ${ }^{16} \mathrm{Na}$ República das Letras de Bayle, toda e qualquer obra estava sujeita ao crivo da crítica, inclusive as suas (BAYLE, 1966: 8a). Idealmente, a corroboração ou refutação de teses deveria se dar sem consequências políticas, sendo

\footnotetext{
15 "Elle a même une avantage qui ne se trouve en aucun autre païs; c'est qu'on y accorde aux imprimeurs une liberté d'une assez grande étenduë, pour faire qu'on s'adresse à eux de tous les endroits de l'Europe, quand on se voit rebuté par les difficultés d'obtenir un privilége [...] Nos presses sont le refuge des Catholiques, aussi-bien que des Reformez [...] Cette honnéte liberté de imprimerie est sans doute un avantage très-favorable au dessein de faire un Journal des Savans".

16 "nous déclarons premiérement, que nous ne prétendons pas étabrlir aucun préjugé ou pour, ou contre les Auteurs" [...] Nous ferons plûtot alors le métier de Rapporteur que celui de Juge, \& nous ferons des extraits aussi fidéles, des Livres qui seront contre nous, que de ceux qui seront pour nous".
} 
o fundamento ético primordial o aperfeiçoamento através do debate. ${ }^{17}$ Para isso, sabia ser necessária a existência de uma organização político-institucional que garantisse a livre circulação de ideias (muito próximo do que chamamos de liberdade de expressão).

Nesse ponto, é importante ressaltar uma diferença entre as situações de exílio dos historiadores Antigos e dos letrados na Idade Moderna. Na Grécia e depois em Roma, jamais se viu aparato censório como o da Inquisição e das monarquias absolutistas. Heródoto, Tucídides e Políbio foram exilados em função de suas alianças políticas, não devido a perseguições contra os livros que escreveram. Seus desterros não foram consequência de suas práticas historiográficas e os conteúdos de seus textos não foram objeto de censura (DILLERY, 2007). Bayle teve suas obras censuradas na França e em outros domínios católicos. Sua Crítica geral da história do calvinismo (1683) foi queimado na praça de Grève, em Paris. Impressores e livreiros foram proibidos, sob pena capital, de imprimir ou vendê-lo. ${ }^{18}$ Por causa do livro, seu irmão mais velho foi detido, torturado e morreu na prisão.

Bayle conheceu o horror da intolerância religiosa. Por isso, o programa editorial de seu jornal, além dos aspectos intelectuais, estava carregado de uma experiência de dor. Por meio da cultura impressa construiu um espaço no qual não deveria existir discriminação religiosa: "não se trata de religião, se trata de ciência: devemos, portanto, por abaixo tudo que divide os homens em facções e considerar somente o ponto sob o qual eles se unem, que é sua qualidade de homens ilustres na República das Letras”. E complementa com uma fórmula que une sua paixão pela erudição e sua concepção tolerante de fé cristã: "sob esse aspecto todos os doutos devem se ver como irmãos" (BAYLE, 1966: 9a). ${ }^{19}$

\section{Considerações finais}

\footnotetext{
${ }^{17}$ Em suas palavras: "nous n'aurrons pour but que de fournir aux Savans de nouvelles occasions de perfectionner l'instruction publique" (BAYLE, 1966: 8A).

${ }^{18}$ A transcrição da sentença pode ser consultada nos documentos anexados por des Maizeaux no seu vie de Pierre Bayle (BAYLE, 1740: cxv).

19 "Il ne s'agit point de Religion; il s'agit de Science: on doit donc mettre bas tous les termes qui divisent les hommes em differentes factions, \& considerer seulement le point dans lequel ils se réünissente, qui est la qualité d'Homme ilustre dans la République des Lettres. En ce sens-là tous les Savans se doivent regarder comme freres".
} 
As ideias de tolerância, que no tempo de Bayle, representaram uma inversão do pensável, hoje mostram seus limites. Mais que de tolerância, em nossos dias se fala de políticas de reconhecimento. A ideia de uma sociedade de doutos, ainda que sem hierarquia entre seus membros, é explicitamente elitista. Embora deva ser dito que Pierre Bayle teve como projeto ampliar a difusão do conhecimento e integrar mais pessoas ao debate público. Também não se pode ignorar que ele, ainda que apresentasse pensamentos heterodoxos, partia de uma perspectiva branca, europeia e masculina. Essa exposição não teve o intuito de heroicizar uma trajetória. Mas acredito que sua experiência no exílio indica que mesmo no modelo centro ocidental existiam tensões. A Europa, diferente da versão higienizada que por vezes se faz, é marcada por uma tradição de conflitos e violências. O próprio espaço de tolerância das Províncias Unidas, além de seus limites internos, tinha como contrapartida o domínio colonial escravocrata que sustentava suas elites.

A experiência do exílio organizou formas de entendimento da história no mundo ocidentalizado. Na modernidade, essas características que analisei no contexto europeu tiveram consequências em outras partes do globo. As diásporas modernas ainda produzem efeitos em nossas percepções contemporâneas da realidade. No caso do Brasil, território marcado pela colonialidade, a relação entre desterritorialização e entendimento do passado inclusive se converteu em tópica historiográfica: "somos ainda hoje uns desterrados em nossa terra" (HOLANDA, 1995: 31).

Bayle, em sua época e a partir do refúgio, propôs reescritas da história, defendeu a tolerância e, ao fazê-lo, talvez tenha provocado uma inversão do que fora até então pensado. Ainda que europeu, apontou para a inadequação de muitos dos padrões de seu tempo, bem como relativizou a suposta superioridade dos valores culturais centro ocidentais. Com a ideia de inadequação, outras lhe são correlatas: deslocamento, separação, movimento e diáspora. Todas noções próximas ao tema do exílio. A potência dessas ideias de deslocamento, da modernidade até o presente, se expressa na forma com que a literatura pós-colonial e decolonial as tem abordado: leituras diaspóricas que desvelam a identidade cindida da Europa, disputas e negociações de entre-lugares, desconstrução das colonialidades. Que inversões do pensado, que novas reescritas da história os deslocamentos, territoriais e epistêmicos, ainda produzirão? 


\section{Fontes}

BAYLE, Pierre (1692). Projet et Fragmens d'un Dictionnaire Critique. Roterdã: chez Reinier Leers.

. (1737a). Oeuvres diverses. Tome Premier. Haye: Compagnie des libraires. . (1737b). Oeuvres diverses. Tome Second. Haye: Compagnie des libraires. . (1740). Dictionnaire historique et critique. 4 vols. Amsterdam: chez P. Brunel. (1966 [1684]). Nouvelles de la république des lettres. Tome I-1684- 1685.

Gèneve: Slatikine Reprints.

CLAUDE, Jean (1707 [1686]). Les plaintes des protestans, cruellement oprimez dans le royaume de France. Londres: par J. Delage.

JURIEU, Pierre (1682). La politique du clergé de France. Haia: chez Barent Beek.

NICOLE, Pierre (1684). Les pretendus reformez convaincus de schisme. Bruxelas: chez Eugene Henry.

TUCÍDIDES (2001). História da Guerra do Peloponeso. Trad. Mário da Gama Kury. $4^{\circ}$ ed. São Paulo: Clássicos Ipri.

\section{Referências bibliográficas}

ALMEIDA, Maria Cecília P. de (2011). O Elogio da Polifonia: Tolerância e Política em Pierre Bayle. Tese (Doutorado em Filosofia) Universidade de São Paulo, São Paulo.

BOST, Hubert. Pierre Bayle. Fayard, 2006.

BUNGE, Wiepe (2018). From Bayle to the Batavian Revolution. Leiden: Brill's studies in intelectual history.

CASSIRER, Ernst (1994). A Filosofia do Iluminismo. Trad. Álvaro Cabral. Campinas: ed. Unicamp.

CERNY, Gerald (1987). Theology, politics and letters at the crossroads of european civilization: Jacques Basnage and the Baylean Huguenot Refugees in the Dutch Republic. Dordrecht: Martinus Nijhoff.

CHAREYRE, Philippe (2002). Démographie et minorités protestantes. Bulletin de la Société de l'Histoire du Protestantisme Français. Vol. 148, pp.867-889, nov./dez.

DELUMEAU, Jean (1989). Nascimento e afirmação da Reforma. Trad. João Pedro Mendes. São Paulo: Pioneira.

DILLERY, John (2007). Exile: the making of the Greek historian. In: GAERTNER, Jean Felix (org.). Writing exile. Leiden: Brill.

GIBNEY, John (2009). Ireland and the Popish plot. National University of Ireland.

GROS, Jean-Michel (2017). Fundamentos e limites de uma teoria filosófica da tolerância: o Comentário filosófico de Pierre Bayle. Revista Enunciação, Rio de Janeiro, Vol.2 - No 2 pp. 178-208, .

HAZARD, Paul (1971). Crise da Consciência Europeia. Lisboa: Cosmos.

HOLANDA, Sérgio Buarque de (1995). Raízes do Brasil. 26ºd. São Paulo: Cia das Letras.

KOSELLECK, Reinhart (1999). Crítica e Crise: uma contribuição à patogênese do mundo burguês. Trad. Luciana Villas-Boas Castelo-Branco. Rio de Janeiro: Contraponto/EdUERJ. 
LABROUSSE, Elisabeth (1985). Pierre Bayle: hétérodoxie et rigorisme. Dordrecht: Martinus Nijhoff Publishers.

LIMA, Luiz Costa (2006). História. Ficção. Literatura. São Paulo: Cia das Letras.

LUGT, Mara van der. Bayle, Jurieu and the Dictionnaire Historique et Critique. UK: Oxford University Press, 2016.

PERRY, I. Elisabeth (1973). From theology to history: french religious controversy and the Reovocation of the Edict of Nantes. Haia: Martinus Nijhoff.

POCOCK, J.G.A (2004). Barbarism and Religion: the Enlightmenments of Edward Gibbon (1737-1764). Cambridge: University Press.

PRICE, J.L. (1998). The Dutch Republic in the Seventeenth Century. New York: St. Martin's Press.

SMITH, Bonnie G. (2003). Gênero e História: homens, mulheres e a prática histórica. Trad. Flávia Beatriz Rossler. Bauru, SP: Edusc.

SPONGBERG, Mary (2002). Writing women's history since the Renaissance. London: Palgrave.

Artigo recebido em 20 de agosto de 2019.

Aprovado em 13 de abril de 2020.

DOI: $10.12957 /$ intellectus.2020.44697 